\title{
Equilibrium
}

Quarterly Journal of Economics and Economic Policy

VOLUME 8 ISSUE 4, 2013

ISSN 1689-765X, (Online) ISSN 2353-3293

http://www.equilibrium.umk.pl/

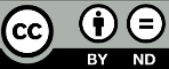

Śledzik K. (2013), Knowledge Based Economy in a Neo-Schumpeterian Point of View, "Equilibrium. Quarterly Journal of Economics and Economic Policy", Volume 8, Issue 4, pp. 67-77, DOI: http://dx.doi.org/10.12775/EQUIL.2013.027

Karol Śledzik*

University of Gdańsk, Poland

\section{Knowledge Based Economy in a Neo-Schumpeterian Point of View}

JEL Classification: $A 11, B 25, O 11$

Keywords: Innovation, Neo-Schumpeterian Economics, Knowledge Based Economy

\begin{abstract}
Schumpeter's growth theory (based on innovations, entrepreneurs, long waves and "creative destruction") seems to be most adequate to discuss principles of the Knowledge Based Economy. In the paper, the author discussed the assumptions of Schumpeter's theory in three subsections: "Long waves" leading to the Knowledge Based Economy, Innovation as a core of Schumpeter's economy, and Neo-Schumpeterian "growth" as a pillar of Knowledge Based Economy. The purpose of this paper is to show the Neo-Schumpeterian paradigms versus Knowledge Based Economy. Conclusions drawn from the study allow to state that definitions and concepts created by Schumpeter nearly over half of the century ago and NeoSchumpeterians nowadays are perfectly in tune with the objectives of the functioning of Knowledge Based Economy in XXI century.
\end{abstract}

\section{Introduction}

We are living in a complex and dynamic world, in which knowledge and innovation are occupying a decisive role for economic development and wealth of nations (World Bank 1999). The economies are increasingly based

(C) Copyright Institute of Economic Research \& Polish Economic Society Branch in Torun Date of submission: January 29, 2013; date of acceptance: September 8, 2013

*Contact: ksledzik@wzr.ug.edu.pl, Faculty of Management, University of Gdańsk, ul. Armii Krajowej 101, 81-824 Sopot, Poland 
on knowledge and information. Knowledge is now recognized as the driver of productivity and economic growth, leading to a new focus on the role of information, technology and learning in economic performance. The term "Knowledge-Based Economy" stems from this fuller recognition of the place of knowledge and technology in modern economies. Knowledge, as embodied in human capital and in technology, has always been central to economic development. But only over the last few years has its relative importance been recognized, and that importance is growing fast. Modern economies are more strongly dependent on the creation, distribution and use of knowledge than ever before. Productivity and employment are expanding fastest in high-technology industries. In the past decade, the high-technology share of manufacturing production and exports has more than doubled, to reach 20-25 per cent. Knowledge-intensive service sectors, are growing even faster. Indeed, it is estimated that more than 50 per cent of Gross Domestic Product (GDP) in the major modern economies is now "knowledge-based" (OECD 1996, p. 3). Moreover, after subprime crisis in the US banking sector, and public debt crisis in Europe there has been a reshuffle in the international "knowledge based arena" in terms of competitive position. Inter alia BRICS countries (Brazil, Russia, India, China and South Africa) soon will be serious competitors not only for Europe, but for the developed economies too (Śledzik 2013). Knowledge Based Economy as a "developed" and "developing" economy operates today in exceptional conditions. Therefore, it is worth to consider theories and concepts of someone who as an economist was way ahead of the era he lived in and was unfairly pushed to the margins of the economic debate. The purpose of this paper is to show the NeoSchumpeterian paradigms versus Knowledge Based Economy. In this paper, the author used the following research methods: a comparative analysis, analogy and deductive inference.

\section{“Long waves" Leading to the Knowledge Based Economy}

In the Neo-Schumpeterian interpretation of the history of technology and economic growth of the last two centuries, we indeed observe four distinct "long waves" (Rosenberg, Frischtak 1984; Louca 2007; Hanush 2007a):

- The first long wave was the "Industrial Revolution" (1780-1840 ca.) (Freeman et al. 1982; Vespagen 2002; Castellacci 2003; Hanush 2007a). The basic innovations were mainly introduced in the textile sector in England, well before the take-off phase of the "Industrial Revolution". They brought a strong potential for productivity increases in the textile sector, which required heavy investments in infrastructures to improve the trans- 
portation system. Moreover, they determined a concentration of workers in factories, and so the shift from the "domestic system" to the "factory system" typical of modern capitalism;

- The second long wave was the "age of steam and railways" (1840-1890 ca.) (Freeman et al. 1982; Castellacci 2003; Hanush 2007a). The improved transportation system gave more locational flexibility to the firms and factories, and sustained high productivity increases, especially in the iron and machinery industries. As the new sectors were growing, more capital was needed to finance high investments. The increased need for capital was a stimulus to the emergence of the joint-stock companies and the stock market, which were the main institutional changes of this age;

- The third wave was the "age of electricity and steel" (1890-1940) (Castellacci 2003; Hanush 2007a). Electricity gave more flexibility to the production system, and more independence on failures in the motors than in the case of steam engines. Both electricity and steel technologies could be applied in many other sectors in the economy, and both pushed towards an enlargements of factories and firms, and thus an increasing importance of economies of scale. As the size of firms was growing, related important organizational changes gradually emerged: the rise of the professional manager, the standardization of tasks in production, the born of the first R\&D (Research and Development) laboratories within large firms (replacing the genial individual inventors of the previous century);

- The fourth long wave was the "age of Fordism and mass production" (1940-1990) (Freeman et al. 1982; Vespagen 2002; Castellacci 2003; Hanush 2007a). The first important basic innovation which gave rise to the new wave was the petrochemical technology to produce oil, which gave a strong impulse to the development of the plastics sector. The other was the internal combustion engine, which pushed forward the automobile industry. The age of mass production was also characterized by an intensive use of the assembling line in the production process, firstly introduced by Henry Ford around 1913 (which was opposed by the labor unions process which greatly decreased the quality of work).

Some authors (Dosi, Freeman, Nelson, Rosenberg, Soete, Winter, Verspagen,) suggest that the new set of basic innovations and globalization could constitute the start of a new technological paradigm and of the "fifth long wave" which is called "Information age" or "Knowledge Based Economy age", and has started in the 90s.

The fifth wave of technology innovation began with the supply of cheap computers, digital computer networks and the Internet. This wave mainly depends on globalization of the economy, information systems which have evolutionary changed the business environment and reduced business distance barriers. The fifth wave was caused by the rapid development of new 
technologies based on knowledge and information. Typical sectors associated with the fifth wave are: aerospace, automotive, biotechnology, cybernetics, electrical engineering, information technology, medical engineering, nanotechnology, nuclear physics, pharmaceutics, robotics and telecommunications.

The ability of the economy to gain competitive advantages from technical change and innovation depends on corporates ability of diffusion, adaptation and application of information and knowledge. Neo-Schumpeterian economics assumes knowledge (in general) and knowledge dynamics, which stands behind innovation, as a priority. The simplified treatment of knowledge as a public good (which is a concern in neoclassical economics) is intellectually no longer profitable. Instead, the complex character of knowledge is emphasized. Besides, in the economy growth has a positive nature because it moves everyone up: "The capitalist process ... progressively raises the standard of life of the masses" (Schumpeter 1942, p. 68). In the processes driving the development Neo-Schumpeterian economics puts a strong emphasis on knowledge, innovation and entrepreneurship.

Concluding, the essential attribute of the Schumpeterian "long wave" concept is the incorporation of technological progress and process of innovations. Entrepreneurship of the fifth wave is part of assumption of Schumpeter's innovation. We can therefore assume that "Schumpeter's fifth wave" is equal to the "Knowledge Based Economy" era.

\section{Innovation as a Core of Schumpeter's Economy}

The birth of modern economics in the second half of the nineteenth century was largely a response to two grand revolutions (Dopfer 2007). The first revolution was a political-economic revolution, and gave individuals high degrees of freedom in their operations. The founders of the discipline had a natural curiosity with respect to the theoretical treatment of coordination under conditions of a free, rather than regulated, market economy. The other one was technological-industrial revolution. Epoch-making inventions (presented in the previous section of this paper), led to a path of unprecedented economic growth and broad structural change. Both the political-economic and the technological-industrial revolution set the fundamental stage for economics as a modern science.

The innovation is considered as an essential driver of competitiveness (Porter, Stern 1999) and economic dynamics (Hanusch, Pyka 2007). Innovation is also a crucial stimulant of Knowledge Based Economy. Despite the fact that innovation was an area of interest to many economists, it was Joseph Schumpeter in 1934 who has recognized the impact of technological 
innovation on the economy. Subsequently, Neo-Schumpeterian economics has developed an impressive body of literature focusing on innovations and spanning micro, meso, and the macro level of economic system dynamics (Dopfer 2007). Schumpeter believed innovation is the center of economic change, causing "gales of creative destruction". "Creative destruction" is a term created by Schumpeter in "Capitalism, Socialism and Democracy" (1942), it is a "process of industrial mutation that incessantly revolutionizes the economic structure from within, incessantly destroying the old one, incessantly creating a new one". He also proposed a taxonomy of technological change based on three stages: invention, innovation and diffusion (Burton-Jones 1999, p. 169). Schumpeter (1934, p. 68) finds that anyone seeking profits must innovate, that is, bring about "the different employment of the economic system's existing supplies of productive means". Innovation has been divided by Schumpeter into five types (Schumpeter 1934, p. 66):

- The launch of a new product or a new kinds of already known product.

- An application of new methods of production or sales (not yet proven in the industry) of a product.

- The opening of a new market (the market on which a branch of the industry was not yet represented).

- Acquiring new sources of supply of raw materials or semi-finished goods.

- The new industry structure, such as the creation or destruction of a monopoly position.

In "Theory of economic development" (1912) and further work (1939, 1943), Schumpeter described development as historical process of structural changes, substantially driven by innovation. He divided the innovation process into four dimensions: invention, innovation, diffusion and imitation. Then he puts the dynamic entrepreneur in the middle of his analysis (1912). In Schumpeter's theory, the possibility and activity of the entrepreneurs, drawing upon the discoveries of scientists and inventors, create completely new opportunities for investment, growth and employment. The profits made from these innovations are then the decisive impulse for new surges of growth, acting as signal to swarms of imitators (Freeman 1987, p. 2). In Schumpeter's analysis, the invention phase or the basic innovation have less of an impact, while the diffusion and imitation process have a much greater influence on the state of an economy. The macroeconomic effects of any basic innovation are hardly noticeable in the first few years, and often even longer. What matters in terms of economic growth, investment and employment, is not the discovery of basic innovation, but rather the diffusion of basic innovation, which is the period when imitators begin to realize the profitable potential of the new product or process and start to invest heavily in that technology (Freeman 1987, p. 5). 
It is worth noting that, according to Schumpeter, invention is not the cause: discovery and execution are "two entirely different things" (Schumpeter 1939, p. 85). "The pure new idea is not adequate by itself to lead to implementation ... . It must be taken up by a strong character and implemented through his influence." (Schumpeter 1912, p. 543). It is not the power of ideas but the power that gets things done. Schumpeter says that "creative destruction" is "the essence of capitalism" (Schumpeter 1942, p. 104). A stationary economy, reactive, repetitive and routine, is a circular flow that admits of no surprises or shocks, "an unchanging economic process which flows on at constant rates in time and merely reproduces itself" (Schumpeter 1939, pp. 35-36). Whereas a stationary feudal economy would still be a feudal economy, and a stationary socialist economy would still be a socialist economy, stationary capitalism is a contradiction in terms (Schumpeter 1943, p. 179). Schumpeter writes that: “... capitalist reality is first and last a process of change" (Schumpeter 1942, p. 77). The change is the essence. Absent creative destruction, what remains would be perpetual imitation and thus not the essence of capitalism at all. According to Schumpeter, innovations are essential to explaining economic growth, and the "entrepreneur" is the central innovator. As Schumpeter (1934), described in "The Theory of Economic Development" the entrepreneur's main function is to allocate existing resources to "new uses and new combinations". One of Schumpeter's most lasting contributions was his insistence that entrepreneurship is at once a unique factor of production and the rare social input that makes economic history evolve.

Schumpeter presents the following entrepreneurship definition: "The function of entrepreneurs is to reform or revolutionize the pattern of production by exploiting an invention or, more generally, an untried technological possibility for producing a new commodity or producing an old one in a new way, by opening up a new source of supply of materials or a new outlet for products, by reorganizing an industry and so on" (Schumpeter 1942, p. 132). The entrepreneur is a pioneer who is able to "act with confidence beyond the range of familiar beacons" (Schumpeter 1942, p. 132). "His characteristic task - theoretically as well as historically - consists precisely in breaking up old, and creating new, tradition" (Schumpeter 1912, p. 92).

In other words, innovation is the "creative destruction" that develops the economy while the entrepreneur performs the function of the change creator. In Schumpeter's work, an entrepreneur is: "Carrying out innovations is the only function which is fundamental in history" (Schumpeter 1939, p. 102). Typical characteristics of entrepreneurs are: intelligence, alertness, energy and determination. Entrepreneurship is innovation and the actualization of innovation. In this point it has to be clearly marked that entrepreneurship cannot be confused with the four complementary functions of invention: 
risk-taking, error-correction and administration (which in Schumpeter's economics of evolution are separate), distinctive and non-entrepreneurial in nature.

Then again, different technological innovations (e.g. steel, vapor or electricity), organizational innovations (e.g. Taylorism, Fordism and Toyotism), as well as social innovations (e.g. the French revolution, the implementation of social security systems) certainly have had important impacts on the social choices of the actors. For example, industrialization led to difficult adaptation processes in which some freedoms have been suppressed and other expanded. Industrialization has led to both higher general levels of human freedom - in the sense of an expanding set of social choices - but also to an expansion of inequality between the freedoms of the actors. This also applies information and communication revolution. On one hand, it has opened up the way for expanding knowledge flows, higher global welfare and a large set of new opportunities (e.g. education through distance, health services etc.). On the other hand it provoked a new threat for the poor in form of the digital divide. Concluding, the important question occurs how to reduce the negative implication of innovation and creative destruction processes and how to promote the positive ones (Hartmann 2009, p. 6).

\section{A Neo-Schumpeterian "Growth" as a Pillar of Knowledge Based Economy}

In the process of economy growth accumulation knowledge takes a central place. According to OECD (OECD 1995): "Knowledge in all its forms plays today a crucial role in economic processes. Intangible investment is growing much more rapidly than physical investment. Firms with more knowledge are winners on the markets. The nations endowed with more knowledge are more competitive. Individuals with more knowledge get better paid jobs. This strategic role is at the root of increasing investments by individuals, firms and nations in all forms of knowledge". In other words, by definition all todays developed economies fill the definition of "knowledge-based economies".

It is worth mentioning that Neo-Schumpeterian Economics analyses the generation, implementation and diffusion of knowledge and technology, putting emphasis on the decisive role and impacts of entrepreneurship and innovation on sectorial dynamics and qualitative change (Saviotti 1996; Hanusch, Pyka 2007). 
The basic principles of Neo-Schumpeterian research paradigm in economics are:

- Schumpeter's basic ideas about the central importance of the innovation process and its disequilibrium character,

- The role of the entrepreneur or the large, bureaucratic R\&D-based firm,

- "Creative destruction" as the driving force behind structural change,

- Aggregate fluctuations at different time scales as inseparable features of the capitalist process of development.

Based on the concepts of Schumpeter (1912, 1939, 1943), a significant series of studies on entrepreneurship, innovation, interactive learning and structural change has been made (Fagerberg et al. 2005; Hanusch, Pyka 2007). A crucial characteristics of Schumpeterian analysis is the reflection that structural changes might be driven by the capabilities of an individual entrepreneur (Schumpeter 1912) and/or big enterprises (Schumpeter 1943). Generally, "Neo-Schumpeterian Economics deals with dynamic processes causing qualitative transformation of economies driven by the introduction of various and multifaceted forms of novelties and the related coevolutionary processes" (Hanusch, Pyka 2007a).

The Neo-Schumpeterian "growth" concept is a particular type of economic growth which is based on the process of creative destruction. The concept of technological development by innovating activities and knowledge creation, as the main engine for economic growth, is not new in economics. It is known that Schumpeter had two various approaches of the innovation process. Firstly, he accented the role of new entrepreneurs entering niches of markets by introducing new ideas and by innovating. Secondly, these entrepreneurs challenged competition via a process of "creative destruction", which was considered as the engine behind economic progress (Schumpeter 1912). In later listings, Schumpeter (1942) paid mainly attention to the key role of large companies as engines for economic growth by accumulating non-transferable knowledge in specific technological areas and markets, which is sometimes defined as "creative accumulation" (Malerba, Orsenigo 1993).

In early phase of Schumpeter's work, an entrepreneur has some special psychological characteristics that make of him a leader (mental freedom of decisions, strength in surmounting the social opposition to change, impulse to fight and creativity). In the late phase of his work, Schumpeter put less focus on the central role of the entrepreneur, giving more significance to the creation of innovation within enterprise. However, no matter whether introduced by a single entrepreneur or within an enterprise, the main point is that basic innovations have a deep impact on the economy. The new technology is at first used only by a few enterprises, but as soon as the opportunities for higher profits become evident to everyone, many more enterprises and sec- 
tors will adopt it. Therefore, the "upswing" of the long wave is the phase in which the new product or process start to diffuse to other enterprises and sectors. When this imitations becomes widespread, more investment in capital and workers are needed. A multiplier process sets in, the effects on the whole economy become evident, and the rate of growth is high and increasing (from the "upswing" to the "prosperity" phase of the business cycle). This is also a time of crucial changes in the structure of the economy: as the new methods diffuse, new sectors become dominant and old sectors decline. That is Schumpeter's "Creative destruction" where competition between firms and sectors is mainly driven by technological factors.

Furthermore, in his "growth theory" Schumpeter recognized the essential role of knowledge accumulation. Without technological change, capital accumulation will not be sustained and the equilibrium (per capita) growth of the economy will tend towards zero. One can consider knowledge in two ways: assigned to the physical and assigned to human capital. Both physical and human capital accumulation depends on technological change. Whereas the incorporation of technology in physical capital has been recognized for a long time, the increasing accumulation of knowledge in human capital has been recognized much more recently. Yet there is little doubt how to create the definition of intellectual capital. There are attempts to measure od intellectual capital level in corporates (Andriessen 2004; Daum 2002; Gosh, Wu 2007; Kujansivu, Lonnqvist 2007; Lev 2001; Sveiby 2010; Śledzik 2012a, $2012 \mathrm{~b}, 2012 \mathrm{c}$ ), but the complexity of the issue significantly hinders the whole process. Either way, there is no doubt that human skills are essential complementary assets to implement, maintain, adapt and use new technologies. From this perspective, human capital and technology are two nonseparable aspects of knowledge accumulation.

\section{Conclusions}

Without doubt, economics is the science which focuses on economic growth of welfare. This assumption is true for all schools in economics: inter alia Neoclassical, Keynesian school as well as the Neo-Schumpeterian economics. But the principles differs significantly among these various approaches. One of the significant differences of Neo-Schumpeterian Economics with respect to other approaches in economics is focusing on knowledge, innovation and entrepreneurship.

The innovation is considered as an essential driver of economy competitiveness. Knowledge and innovation was an area of interest to many economists but it was Joseph Schumpeter who recognized the impact of technological innovation on an economy what nowadays we can define as 
a Knowledge Based. Subsequently, Neo-Schumpeterian Economics has developed an impressive body of literature focusing on innovations in economy based on knowledge. The analysis allows to state that definitions and concepts created by Schumpeter nearly over half of the century ago and NeoSchumpeterians nowadays are perfectly in tune the objectives of the functioning of Knowledge Based Economy in XXI century.

\section{References}

Andriessen D. (2004), Making sense of Intellectual capital, Designing a method for the valuation of intangibles, Elsevier, Oxford UK

Burton-Jones A. (1999), Knowledge Capitalism - Business, Work, and Learning in the New Economy, Oxford University Press, Oxford.

Castellacci F, (2003), A neo-Schumpeterian Approach to why Growth Rates Differ, Working paper 04/03, August 2003, Centre for technology, innovation and culture.

Daum J.H. (2002), Intangible Assets and Value creation, John Wiley \& Sons, United Kingdom.

Dopfer K. (2007), The pillars of Schumpeter's economics: micro, meso, macro [in:] H. Hanusch, A. Pyka (eds.), Elgar Companion on Neo-Schumpeterian Economics, Edward Elgar, Cheltenham,

Fagerberg J., Mowery D.C., Nelson R.R. (ed.) (2005), The Oxford Handbook of Innovation, Oxford University Press, Oxford, New York

Freeman C., Clark, J., Soete L. (1982), Unemployment and technical innovation, Pinter, London.

Freeman C. (1987), Technology Policy and Economic Performance: Lessons from Japan, Frances Printer Publishers, London, New York

Ghosh D., Wu A. (2007), Intellectual capital and capital markets: additional evidence, "Journal of Intellectual Capital", Vol. 8 No. 2.

Hanusch H., Pyka, A. (2007), Introduction [in:] Hanusch H., Pyka, A. (eds.), Elgar Companion to Neo-Schumpeterian Economics, Edward Elgar, Cheltenham,

Hanusch H., Pyka, A. (2007a), Elgar Companion to Neo-Schumpeterian Economics, Edward Elgar, Cheltenham.

Hartmann D. (2009), Sen meets Schumpeter: Towards an agent oriented theory of inequality and qualitative change, www.capabilityapproach.com.

Kujansivu P., Lonnqvist A. (2007), Investigating the value and efficiency of Intellectual capital, "Journal of Intellectual Capital", Vol. 8 No. 2.

Lev B. (2001), Intangibles, Management measuring and reporting, The brooking institution, Washington

Louca F. (2007), Long waves, the pulsation of modern capitalism, "Industrial Corporate Change", Vol. 2.

OECD (1995), Technology, Productivity and Job Creation, Vol. I and II, The OECD Job Strategy, Paris,

OECD (1996), The knowledge based economy, General Distribution OCDE/GD(96)102 
Porter M.E., Stern, S. (1999), The New Challenge to America's Prosperity: Findings from the Innovation Index, Council on Competitiveness, Washington, DC.

Rosenberg N., Frischtak C.R. (1984), Technological innovation and long waves, "Cambridge Journal of Economics".

Saviotti P.P. (1996), Technological Evolution, Variety and the Economy, Cheltenham, Edward Elgar

Saviotti P.P., Pyka A. (2004), Economic development by the creation of new sectors, "Journal of Evolutionary Economics", Vol. 14, No. 1.

Schumpeter J.A. (1912), The Theory of Economic Development, tenth printing 2004, Transaction Publishers, New Brunswick, New Jersey.

Schumpeter J.A. (1934), The theory of economic development: an inquiry into profits, capital, credit, interest and the business cycle, Harvard Economic Studies, Vol. 46, Harvard College, Cambridge, MA.

Schumpeter J.A. (1939), Business Cycles: A Theoretical, Historical and Statistical Analysis of the Capitalist Process, 2 Vol., New York: McGraw-Hill.

Schumpeter J.A. (1942), Capitalism, Socialism and Democracy, 3rd edn, London: George Allen and Unwin.

Schumpeter J.A. (1943), 'Capitalism in the postwar world', in S.E. Harris (ed.), Postwar Economic Problems, in Essays (Schumpeter, 1951).

Sveiby K.E. (2010), Methods for Measuring Intangible Assets, http://www.sveiby. com/articles/IntangibleMethods.htm.

Śledzik K. (2012a), A taxonomy of intellectual capital: 2006-2009 Polish Banks Perspective, "Financial Accounting eJournal", Vol. 4, No 150.

Śledzik K. (2012b), How to Measure Intangible Resources in Listed Companies ,Theory of management 5 The Selected Problems for the Development Support of Management Knowledge Base, Faculty of Management Science and Informatics, University of Zilina.

Śledzik K. (2012c), The Intellectual Capital Performance of Polish Banks: An Application of VAIC ${ }^{\mathrm{TM}}$ Model, "Accounting, Corporate Governance, Law \& Institutions eJournal”, Vol. 98, No. 4.

Śledzik K. (2013), BRICS, MIST (MIKT) or G5 - Which “Club” of Economies has the biggest growth potential?, "Economic Growth eJournal”, Vol. 5, No. 5.

Verspagen B. (1991), A new empirical approach to catching up or falling behind, "Structural change and economic dynamics", Vol. 2, No. 2

World Bank (1999), World development report 1998-1999: Knowledge for Development, Oxford University press, New York. 